\title{
Mechanisms of texture formation in thin-film systems $\mathrm{Ni}_{1-x} \mathbf{W}_{x} \mid \mathrm{TiN}$
}

\author{
M.S.Sungurov, T.V.Sukhareva, V.A.Finkel \\ National Science Center "Kharkiv Institute of Physics and Technology", \\ 1 Akademicheskaya Str., 61108 Kharkiv, Ukraine
}

\section{Received February 17, 2018}

The article is devoted to study of the problem of establishing the nature and mechanisms of processes of texture formation in both components of a thin layer system $\mathrm{Ni}-$ 9.5 at. \% W/TiN. Comparative analysis of the structure and properties of two-layer compositions based on tapes made of ferromagnetic $\mathrm{Ni}-5$ at. \% $\mathrm{W}$ alloy and paramagnetic $\mathrm{Ni}$ - 9.5 at. $\% \mathrm{~W}$ alloy with TiN coating was carried out using X-ray diffraction analysis. It was established that the mechanism and kinetics of the texture formation processes are conduced by peculiarities of the redistribution of the stress state in both subsystems of the two-component "substrate-coating" system. Within the framework of the present work, the strategy for obtaining the textured substrates based on $\mathrm{Ni}-9.5$ at. $\% \mathrm{~W}$ alloy is developed, which makes it possible to create effective architecture of the high-temperature superconductors of the second generation (2G HTS) with the high current-carrying capacity.

Keywords: stress state, cubic texture, Ni-W, TiN, 2G HTS.

Статья посвящена исследованию проблемы установления природы и механизмов процессов текстурообразования в обеих компонентах тонкослойной системы $\mathrm{Ni}$ 9.5 at. \% WTiN. Путем сравнительного изучения двухслойных композиций на основе лент из ферромагнитного сплава $\mathrm{Ni}-5$ at. \% W и парамагнитного сплава $\mathrm{Ni}-9.5$ at. $\%$ W с покрытием TiN методами рентгеноструктурного анализа установлено, что механизм и кинетика процессов текстурообразования обусловлены особенностями перераспределения напряженного состояния в обеих подсистемах двухкомпонентной системы "подложка - покрытие". В рамках настоящей работы развита стратегия получения текстурированных подложек на основе сплава $\mathrm{Ni}-9.5$ at. \% W, обеспечивающих возможность создания әффективной архитектуры высокотемпературных сверхпроводников второго поколения (2G HTS) с высокой токонесущей способностью.

Механізми формування текстури у тонкошарових системах $\mathrm{Ni}_{1-x} \mathbf{W}_{\boldsymbol{x}} \mid \mathrm{TiN}$. M.C.Сунгуров, T.В.Сухарєва, В.А.Фінкель.

Стаття присвячена дослідженню проблеми встановлення природи та механізмів процесів формування текстури в обох компонентах тонкошарової системи $\mathrm{Ni}-9.5$ at. $\% \mathrm{~W} / \mathrm{TiN}$. Шляхом порівняльного вивчення двошарових композицій на основі стрічок із феромагнітного сплаву $\mathrm{Ni}-5$ at. \% W та парамагнітного сплаву $\mathrm{Ni}-9.5$ at. \% W 3 покриттям TiN методами рентгеноструктурного аналізу встановлено, що механізм та кінетика процесів формування текстури обумовлені особливостями розподілу напруженого стану в обох підсистемах двокомпонентної системи "підложка - покриття". У рамках проведеного дослідження розвинуто стратегію отримання текстурованих підложок на основі сплаву $\mathrm{Ni}-9.5$ at. \% W, спроможних забезпечити можливість створення ефективної архітектури високотемпературних надпровідників другого покоління (2G HTS) з високою струмонесною спроможністю. 


\section{Introduction}

Studies on the development of high-temperature superconductors of the second generation (2G HTS), which have been going on for more than 30 years, have shown that the only possibility of $2 \mathrm{G}$ HTS realization with the high current-carrying capacity at the level of $j_{c}=10^{5}-10^{6} \mathrm{~A} / \mathrm{cm}^{2}$ at the boiling point of liquid nitrogen is the applying of thin quasi-monocrystalline superconducting films, in which electric current flows in the plane of propagation of a charge [1-5]. As is known, for the most promising high-temperature superconductor $\mathrm{YBa}_{2} \mathrm{Cu}_{3} \mathrm{O}_{7-\delta}$ this plane is the basal plane of $\mathrm{CuO}_{2}$ in the rhombic lattice with space group $P / 3 m$.

The architecture of $2 \mathrm{G}$ HTS [6-12] includes the following components:

1) Metallic substrate (single-phase alloys with FCC crystal structure: as a rule $\mathrm{Ni}-\mathrm{W}$ alloys of different compositions are widely used).

2) Buffer dielectric layer (nitrides or oxides of transition elements with FCC structure, in particular titanium nitride $\mathrm{TiN}$ ).

3) Superconducting coating $\mathrm{YBa}_{2} \mathrm{Cu}_{3} \mathrm{O}_{7-\delta}$ (YBCO - 123).

Such architectures, in principle, provide the possibility of implementing the following orientation relations: $\{001\} \mathrm{Ni}-$ $W \|\{001\} T$ TiN $\|\{001\}$ YBCO-123 [11]. To reduce the level of ferromagnetic losses during the transfer of superconducting current, the metal substrate should be in a non-magnetic state at the low temperatures $[13,14]$.

At the low concentrations of tungsten, $\mathrm{Ni}_{1-x} \mathrm{~W}_{x}$ alloys are in the ferromagnetic state. At tungsten concentration $x \geq 0.095$, the alloy goes into the paramagnetic state in the entire range of the low temperatures. However, as the content of tungsten increases, the energy of stacking faults $E_{s f}$ decreases significantly. This leads to decrease in the degree of cubic texture in deformed $\mathrm{Ni}-\mathrm{W}$ alloys after recrystallization annealing [15-17].

It was established earlier [18-23] that deposition of a TiN layer on the paramagnetic ribbon of $\mathrm{Ni}-9.5$ at. \% W leads to increasing in effects of texture formation in both components of the system $\mathrm{Ni}-\mathbf{9 . 5}$ at. \% W/TiN.

In this connection, the main purpose of the study is to establish the nature and physical mechanisms of the processes of texture formation in the system $\mathrm{Ni}-9.5$ at. $\% \mathrm{~W} \mid \mathrm{TiN}$, providing the possibility of obtaining the high-temperature superconduc- tors with the high current-carrying capacity.

We believe that the promising way of realization of the thin-film composition of "Ni -9.5 at. $\% \mathrm{~W} \mid \mathrm{TiN} "$ is the control of the level of stresses on the interphasic boundary in the system "metallic substrate buffer coating".

To achieve the goal, the following research program was implemented:

- Synthesis of $\mathrm{Ni}_{1-x} \mathrm{~W}_{x}$ alloys in the range of concentrations $0 \leq x \leq 0.095$.

- Obtaining and certification of the longlength ribbons based on $\mathrm{Ni}_{1-x} \mathrm{~W}_{x}$ alloys with different composition.

- Optimization of the conditions for TiN deposition on tapes of $\mathrm{Ni}_{1-x} \mathrm{~W}_{x}$ alloys.

- Investigation of structural features of both components of the two-layer composition $\mathrm{Ni}_{1-x} \mathrm{~W}_{x} \mid \mathrm{TiN}$.

- Investigation of the stressed state in the two-layer systems $\mathrm{Ni}_{1-x} \mathrm{~W}_{x} \mid \mathrm{TiN}$.

\section{Materials and methods}

Technology for obtaining the samples for further studying (2.1) and features of the research methods of thin-film compositions $\mathrm{Ni}_{1-x} \mathrm{~W}_{x} \mid \mathrm{TiN}(2.2)$ are discussed below.

\subsection{Preparation of samples for investigation}

\subsubsection{Synthesis of $N i_{1-x} W_{x}$ alloys}

The initial materials for obtaining the $\mathrm{Ni}-\mathrm{W}$ alloys were $\mathrm{Ni}$ and $\mathrm{W}$ powders with 99.98-99.99 \% purity (by metallic impurities). The following methods were used for purification from gaseous impurities (the main impurity is oxygen represented as nickel and tungsten oxides): 1) the heat treatment at temperatures $T=1120 \mathrm{~K}$ for purification of $\mathrm{Ni}$ powder; 2) for refinement of $W$ powder was applied the high-temperature treatment at $T=1470 \mathrm{~K}$ in reducing $\mathrm{Ar}+4 \% \mathrm{H}_{2}$ gaseous mixture flow [24]. X-ray diffraction, optical microscopy, and magnetic susceptibility measurements showed that oxides of nickel and tungsten were not present for a given heat treatment.

The alloys were synthesized by means of powder metallurgy. The original components were thoroughly mixed in the required proportions $(0-9.5$ at. $\%$ W). Then the powder mixture was compressed using a standard laboratory press in the form of parallelepipeds of dimensions $10 \times 50 \times 2 \mathrm{~mm}^{3}$. Finally the samples were sintered under deep vacuum conditions $\left(p \sim 10^{-6}\right.$ Torr $)$ at $T$ $\sim 1550 \mathrm{~K}$ during $t=4 \mathrm{~h}$. 
For the samples attestation X-ray diffraction analysis was used (Dron UM-1, CuK $\alpha$ irradiation). It was established that obtained alloys $\mathrm{Ni}_{1-x} \mathrm{~W}_{x}$ in the chosen range of concentrations were single-phase and possessed FCC structure.

\subsubsection{Obtaining of ribbons based on Ni-W} alloys of different composition

Obtained ingots were rolled up to 50$100 \mu \mathrm{m}$ at room temperatures to perform metallic tape. As was shown earlier [19], the optimal condition for mechanical treatment of the Ni-W alloys is cold rolling with the high reduction ratio without intermediate annealing. The idea of using such a technique is that the presence of stresses acquired during the cold deformation of the sample can contribute to formation of the cubic texture of recrystallization due to increase in $E_{s f}$. The total degree of the coldrolling deformation was about $95 \%$. The final thickness of the ribbon after cold rolling was $d \sim 100 \pm 5 \mu \mathrm{m}$. The resulting operation during the tape production was hightemperature annealing at $T \sim 1373 \mathrm{~K}$ during $t=2 \mathrm{~h}$.

\subsubsection{The deposition of TiN coating}

TiN coatings were obtained by vacuum arc deposition method [25-27] using as a cathode material the technically pure titanium VT-1. Unlike most studies on the deposition of nitride coatings, TiN deposition was performed not only on the "face", i.e. which is directed to the cathode, but also on the "shady" side of the substrate, located outside the line of sight of the cathode spot.

Below are given the data of experiments on deposition of $\mathrm{TiN}$ on ribbons based on the ferromagnetic $\mathrm{Ni}-5$ at. $\% \mathrm{~W}$ alloy and the paramagnetic $\mathrm{Ni}-\mathbf{9 . 5}$ at. $\% \mathrm{~W}$ alloy under the previously optimized [see, for example, [22] parameters: the arc current $I=80 \mathrm{~A}$; the negative potential of the substrate $U=$ $-300 \mathrm{~V}$; the pressure of nitrogen in vacuum chamber $p_{\mathrm{N}}=1.8 \cdot 10^{-2}$ Torr. The deposition time of the coating varied within $\tau_{\mathrm{TiN}}=60-$ 900 s.

\subsection{Methods of the investigation of thin-film systems $\mathrm{Ni}_{1-x} \mathrm{~W}_{x} \mid \mathrm{TiN}$}

2.2.1. Method of determination of thickness of TiN coating

The method used to determine thickness of the TiN coating layer is based on measuring the intensity of X-ray interference from the material of flat substrate under influence of the coating [28, 29].

The intensity of a beam reflected from the crystalline plane $(h k l)$ of a sample with the coating of thickness $h$ and linear absorption coefficient $\mu_{\mathrm{TiN}}=880 \mathrm{~cm}^{-1}$, is:

$$
I_{h k l}^{\mathrm{NiW}_{(}}(h)=I_{h k l}^{\mathrm{NiW}}(0) \cdot \exp \left(-2 \mu_{\mathrm{TiN}} \cdot h / \cos (\theta)\right),
$$

where $I_{h k l}^{\mathrm{NiW}}(h)$ is the intensity of a beam reflected from a sample with coating; $I_{h k l} \mathrm{NiW}_{(0)}$ is the intensity of a beam reflected from a sample without coating; $\mu_{\mathrm{TiN}}$ is the linear coefficient of absorption of $\mathrm{TiN} ; h$ is the thickness of the coating layer; $\theta$ is the angle of reflection.

Formula (1) makes it possible to determine the thickness of the coating, regardless of the composition of the alloy. To avoid errors in determining the thickness, resulting from the possibility of the processes of texture formation passing in the substrate, the experiments were carried out simultaneously on two samples, which were in identical conditions. Since the absorption coefficient $\mathbf{k}_{i j}$ is a second-rank polar tensor, in general, the absorption surface is an ellipsoid [30]. However, for crystal systems of the highest order the absorption coefficient reduces to scalar. Thus, $\mu_{\mathrm{TiN}}$ for cubic crystals ceases to depend on the direction [31]. In this paper, the sample of $\mathrm{Ni}-5$ at. $\% \mathrm{~W}$ ribbon with the stable cubic texture of recrystallization served as a test object for determination of $h_{\mathrm{TiN}}$. Since the thickness of the coatings varied in the range of $h_{\mathrm{TiN}}$ 0-5 $\mu \mathrm{m}$, this made it possible to carry out the X-ray diffraction studies of both the coating and the substrate.

2.2.2. Method of texture analysis of twolayer system $\mathrm{Ni}_{1-x} \mathrm{~W}_{x} \mid \mathrm{TiN}$

In order to determine fine variations of texture in the $\mathrm{Ni}_{1-x} \mathrm{~W}_{x} \mid \mathrm{TiN}$ system, the classical methods [32] were supplemented by an algorithm of planar texture characterization based on the construction and analysis of diagrams of the angular distribution of intensities from crystallographic planes. In the present work it was most important to study the cubic planes (h00) of the FCC lattices of the metallic ribbon and coating in various directions. The samples were rotated by angle $\varphi$ about the normal direction with $15^{\circ}$ step. The validity of the hypothesis of realization of the perfect cubic texture was verified using $\chi^{2}$ method [33]. The 
$\chi^{2}$ value was calculated for $n=23$ degrees of freedom.

\subsubsection{Method of determination of internal stresses in two-layer thin-film system $\mathrm{Ni}_{1-x} \mathrm{~W}_{x} \mid$ TiN}

To establish the possibility of appearance and nature of the interphase stresses in the systems under investigation, the well-known method $\sin ^{2} \psi$ was applied [34, 35]. In the general case it is convenient to represent the stress state by means of the following equation:

$$
\begin{aligned}
& \varepsilon_{\varphi, \psi}=\frac{1+v}{E} \cdot \sigma_{\varphi} \cdot \sin ^{2} \psi-\frac{v}{E} \cdot\left(\sigma_{1}+\sigma_{2}\right)= \\
= & -\operatorname{ctg} \varphi_{0}\left(\varphi_{\varphi, \psi}-\varphi_{0}\right),
\end{aligned}
$$

where $\varepsilon_{\varphi, \psi}$ is the deformation of a sample in a given direction; $v$ and $E$ are respectively, the Poisson ratio and the Young's modulus, $\theta_{\varphi, \psi}$ is the diffraction angle; $\theta_{0}-$ the diffraction angle for a sample in the unstressed state; $\sigma_{\varphi}$ is the stress in a given direction; $\left(\sigma_{1}+\sigma_{2}\right)$ is sum of the main normal stresses in the plane of a sample. It is generally accepted that the component $\sigma_{3} \approx 0$ in view of the fact that $\mathrm{X}$-rays penetrate the sample only in a small part of its thickness.

From Eq. (2) it follows:

$$
\begin{gathered}
\varphi_{p h i, \psi}=\varphi_{0}+\frac{v}{E} \cdot\left(\sigma_{1}+\sigma_{2}\right) \cdot \operatorname{tg} \varphi_{0}- \\
-\frac{1+v}{E} \cdot \operatorname{tg} \varphi_{0} \cdot \sigma_{0} \cdot \sin ^{2} \psi .
\end{gathered}
$$

It should be taken into account that two factors hamper the direct application of the classical technique for determining the first-order macro strains using the $\sin ^{2} \psi$ method:

1) The studied compositions $\mathrm{Ni}_{1-x} \mathrm{~W}_{x} \mid \mathrm{TiN}$ are two-layer systems.

2) There is a rather strong texture in the both components of the system "substratecoating".

These circumstances indicate that the accuracy of determining the stress state of the research objects is not high enough.

From Eq. (3), one can obtain the following expressions, describing stresses $\sigma_{\varphi}$ for both components of $\mathrm{Ni}_{1-x} \mathrm{~W}_{x} \mid \mathrm{TiN}$ in a given direction:

$$
\begin{gathered}
\Delta \varphi_{\mathrm{TiN}}=\left(\varphi_{\varphi, \psi}-\varphi_{0}\right)_{\mathrm{TiN}}= \\
=-\frac{1+v_{\mathrm{TiN}}}{E_{\mathrm{TiN}}} \cdot \operatorname{tg} \varphi_{\psi=0}^{\mathrm{TiN}} \cdot \sigma_{\varphi}^{\mathrm{TiN}} \cdot \sin ^{2} \psi, \\
\Delta \varphi_{\mathrm{Ni}-\mathrm{W}}=\left(\varphi_{\varphi, \psi}-\varphi_{0}\right)_{\mathrm{Ni}-\mathrm{W}}= \\
=-\frac{1+v_{\mathrm{Ni}-W}}{E_{\mathrm{Ni}-\mathrm{W}}} \cdot \operatorname{tg} \varphi_{\psi=0}^{\mathrm{Ni}-W} \cdot \sigma_{\varphi}^{\mathrm{Ni}-W} \cdot \sin ^{2} \psi .
\end{gathered}
$$

On the diffractometer Dron UM-1 ( $\mathrm{CuK}_{\alpha}$ - irradiation) in the step scan mode (step $2 \theta=0.01^{\circ}$ ) the diffraction lines $(400)_{\mathrm{NiW}}$ and $(200)_{\mathrm{TiN}}$ for several values of the angle $\psi$ were registered. Narrow range of the inclination angles caused by the presence of enough strong texture. The line profiles for determining the angular position of the center of mass were approximated by the Gaussian function. In accordance with equations (4), the dependences $\Delta 2 \theta\left(\sin ^{2} \psi\right)$ were built for both components of the thin-layer system and rectified by the least squares method.

\section{Results and discussion}

It was established earlier [36] that kinetics of the phase and texture formation processes in $\mathrm{Ni}_{1-x} \mathrm{~W}_{x} \mid$ TiN is significantly dependent on the coating deposition conditions. This is evidenced first of all by the fact that the rate of TiN deposition on the "front" side of the substrate is noticeably higher than on the "shadow" one. Besides that the difference in the deposition rate decreases with increasing $p_{N}$.

The results given below refer to the case of the coating deposition on the "shadow" side of the substrate at fixed conditions (coating thickness $h_{\mathrm{TiN}} \approx 1 \mu \mathrm{m}$ at $\tau_{\mathrm{TiN}}=$ $120 \mathrm{~s}$ ), at which, as mentioned above (see Introduction) processes of texture formation in the system $\mathrm{Ni}-9.5$ at. $\% \mathrm{~W} \mid \mathrm{TiN}$ are expressed most strongly.

\subsection{Study of texture in systems$$
\mathrm{Ni}-5 \text { at. \% WTiN and } \mathrm{Ni}-
$$$$
9.5 \text { at. \% WTIN }
$$

\subsubsection{System Ni - 5 at. \% WTiN}

Fig. 1 shows "circular" diagrams of the angular distribution of the diffraction intensity form the cubic planes $(h 00)$ of a ribbon of $\mathrm{Ni}-5$ at. $\% \mathrm{~W}$ alloy (see Fig. 1a) and both components of the two-layer system $\mathrm{Ni}-5$ at. $\%$ W|TiN (see Fig. 1b). It can be seen that formation of the strong cubic texture takes place both in the $\mathrm{Ni}-5$ at. 


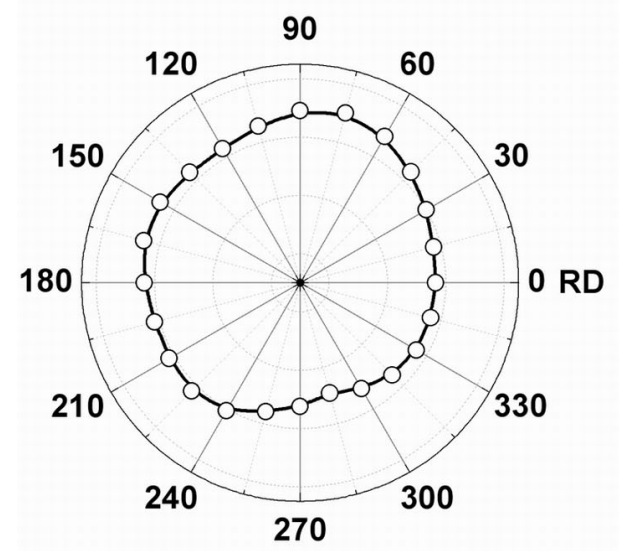

a)

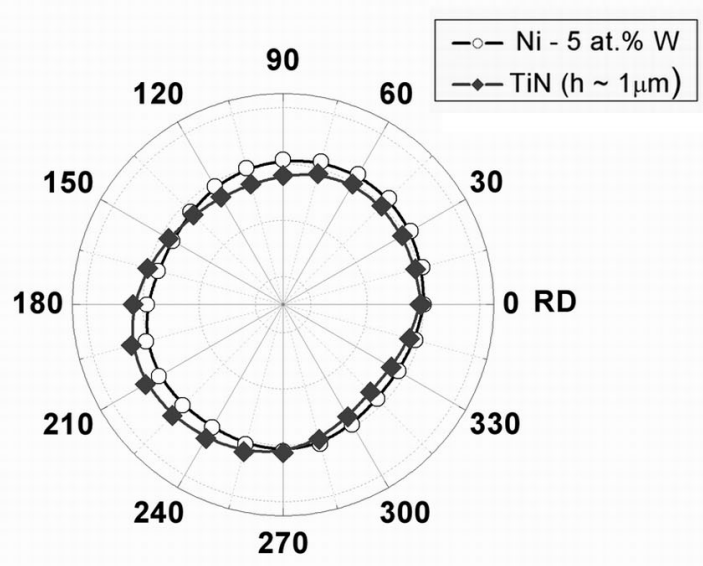

b)

Fig. 1. Diagrams of the angular distribution of diffraction from the cubic plane (200): a) sample of $\mathrm{Ni}-5$ at. $\% \mathrm{~W}$ without coating; b) sample of $\mathrm{Ni}-5$ at. $\% \mathrm{~W}$ with coating $\mathrm{TiN}\left(h_{\mathrm{TiN}} \sim 1 \mu \mathrm{m}\right)$.

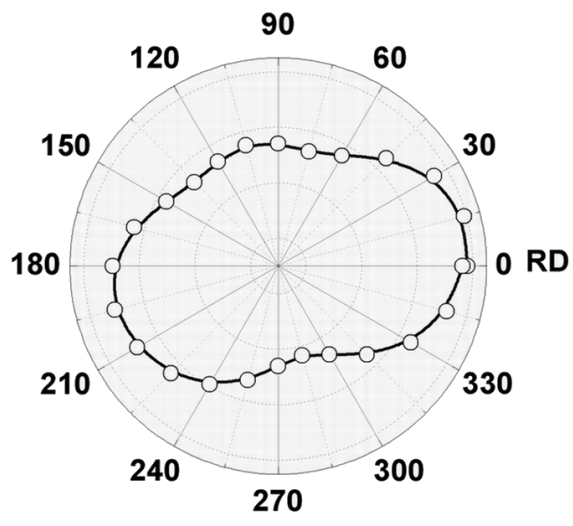

a)

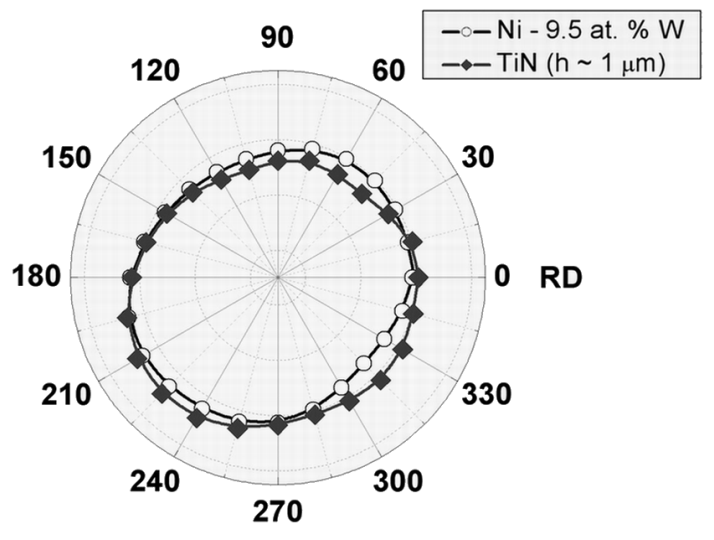

b)

Fig. 2. Diagrams of the angular distribution of diffraction from the cubic plane (200): a) sample of $\mathrm{Ni}-9.5$ at. $\% \mathrm{~W}$ without coating; b) sample of $\mathrm{Ni}-9.5$ at. $\% \mathrm{~W}$ with coating $\mathrm{TiN}\left(h_{\mathrm{TiN}} \sim 1 \mu \mathrm{m}\right)$.

$\% \mathrm{~W}\left(\chi^{2} \mathrm{Ni-5}\right.$ at.\%W $\left.=0.012\right)$ substrate and in the TiN coating $\left(\chi^{2} \mathrm{TiN}=0.005\right)$ layer.

\subsubsection{System Ni - 9.5 at. \% WTiN}

Fig. 2 shows "circular" diagrams constructed in a similar way for metallic ribbon $\mathrm{Ni}-9.5$ at. $\% \mathrm{~W}$ and both components of the system $\mathrm{Ni}-\mathbf{9 . 5}$ at. $\% \mathrm{~W} / \mathrm{TiN}$. The results shown in Fig. 1 and Fig. 2 are qualitatively similar. However, the degree of the cubic texture in the original tape of $\mathrm{Ni}-$ 9.5 at. $\% \mathrm{~W}\left(\chi^{2} \mathrm{Ni}-9.5\right.$ at. $\left.\% \mathrm{~W}=0.044\right)$ is noticeably lower than the degree of texture in the tape of $\mathrm{Ni}-5$ at. $\% \mathrm{~W}$ ribbon.

It should be noted that the presence of the cubic texture is observed (see Fig. 2b) in the both subsystems of $\mathrm{Ni}-9.5$ at. $\%$ W|TiN. After deposition of TiN layer onto $\mathrm{Ni}$ -9.5 at. $\% W$ substrate the value of $\chi^{2}$ for metallic component of the system $\mathrm{Ni}-9.5$ at. $\% \mathrm{~W} \mid \mathrm{TiN}$ decreased: $\chi^{2} \mathrm{Ni}-9.5$ at. $\% \mathrm{~W}$ TTiN $=$ 0.013. For TiN layer "the texture parameter" equals $\chi^{2} \mathrm{TiN}=0.009$.

\subsection{The investigation of stresses in systems $\mathrm{Ni}-5$ at. \% WITIN and $\mathrm{Ni}-9.5$ at. \% W|TiN}

To study the nature of the processes of texture formation based on the concept of the evolution of cubic texture under the action of interfacial stresses, it is necessary to investigate the level of macro-stresses arising in the two-layer system "substratecoating". In this regard the most effective way to determine the stresses of the first order is to implement and use the known 

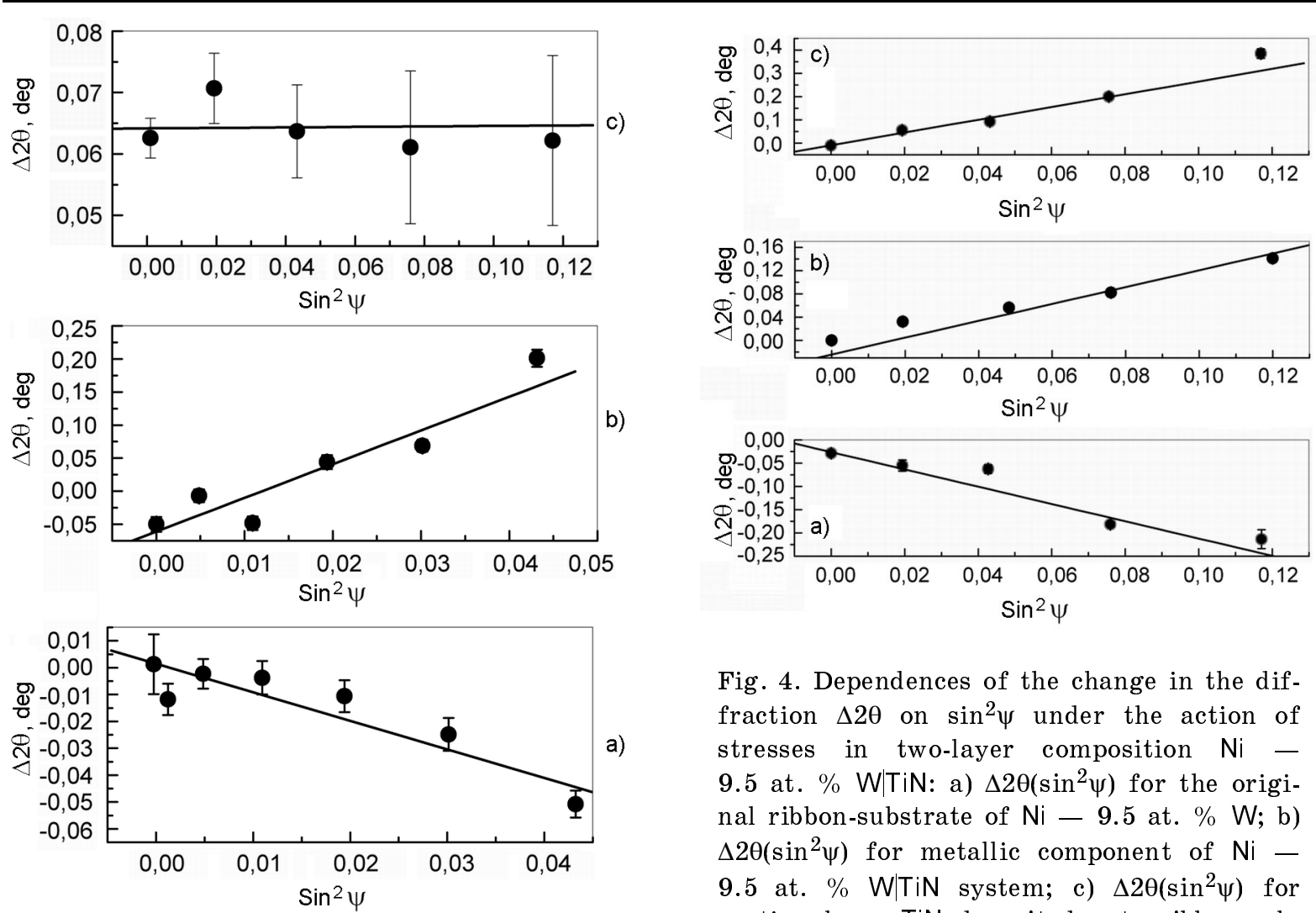

Fig. 3. Dependences of the change in the diffraction $\Delta 2 \theta$ on $\sin ^{2} \psi$ under the action of stresses in two-layer composition $\mathrm{Ni}-5$ at. $\%$ W/TiN: a) $\Delta 2 \theta\left(\sin ^{2} \psi\right)$ for the original ribbon-substrate of $\mathrm{Ni}-5$ at. $\% \quad \mathrm{~W} ; \quad$ b) $\Delta 2 \theta\left(\sin ^{2} \psi\right)$ for metallic component of $\mathrm{Ni}-$ 5 at. $\%$ W/TiN system; c) $\Delta 2 \theta\left(\sin ^{2} \psi\right)$ for coating layer TiN deposited onto ribbon-substrate $\mathrm{Ni}-5$ at. $\%$ W.

" $\sin ^{2} \psi "$ method in respect of both components of the thin-layer composition $\mathrm{Ni}_{1-x} \mathrm{~W}_{x} \mid \mathrm{TiN} "$.

\subsubsection{Stresses in the system $\mathrm{Ni}-5$ at. \% WTiN}

Fig. 3 shows the dependence of variation of the diffraction angle $\Delta 2 \theta$ on $\sin ^{2} \psi$ under action of the stresses in the initial metallic tape and both components of the two-layer system $\mathrm{Ni}-5$ at. \% W|TiN. One can see that in the tape after mechanical and thermal treatment (Fig. 3a) tensile stresses initially present. The small value of the slope angle of the curve $\Delta 2 \theta\left(\sin ^{2} \psi\right)$ indicates relatively low values of stresses in the tape. The data shown in Fig. $3 \mathrm{~b}$ indicate that the tensile stresses in the metal component of the system under influence of the coating are replaced by the compressive ones, whereas (see Fig. 3c) the

Fig. 4. Dependences of the change in the diffraction $\Delta 2 \theta$ on $\sin ^{2} \psi$ under the action of stresses in two-layer composition $\mathrm{Ni}-$ 9.5 at. $\%$ W TiN: a) $\Delta 2 \theta\left(\sin ^{2} \psi\right)$ for the original ribbon-substrate of $\mathrm{Ni}-\mathbf{9 . 5}$ at. $\% \mathrm{~W}$; b) $\Delta 2 \theta\left(\sin ^{2} \psi\right)$ for metallic component of $\mathrm{Ni}-$ 9.5 at. $\%$ W TTiN system; c) $\Delta 2 \theta\left(\sin ^{2} \psi\right)$ for coating layer TiN deposited onto ribbon-substrate $\mathrm{Ni}-9.5$ at. $\% \mathrm{~W}$.

stresses in the TiN coating layer are practically absent.

3.2.2. Stresses in the system $\mathrm{Ni}-9.5$ at. $\%$ WTIN

Fig. 4 shows the dependence of variation of the diffraction angle $\Delta 2 \theta$ on $\sin ^{2} \theta$ under the stresses action in the initial metallic tape and both components of the two-layer system $\mathrm{Ni}-\mathbf{9 . 5}$ at. \% W/TiN.

As can be seen the level of stresses in the substrate based on alloy $\mathrm{Ni}-9.5$ at. $\% \mathrm{~W}$ (see Fig. 4a) significantly exceeds the level of stresses in the substrate of $\mathrm{Ni}-5$ at. \% W. As a result of TiN deposition the tensile stresses in the metallic component of the system $\mathrm{Ni}-9.5$ at. $\% \mathrm{~W} \mid \mathrm{TiN}$ are replaced by the compressive stresses (Fig. 4b). However in contrast to the $\mathrm{Ni}-5$ at. \% W/TiN system, there are strong compressive stresses in the TiN coating layer deposited on the $\mathrm{Ni}-9.5$ at. $\%$ W substrate (Fig. 4c).

\subsection{The nature of the processes of texture formation in two-layer systems $\mathrm{Ni}_{1-x} \mathrm{~W}_{x} \mid$ TiN}

The results of the combined study of textural effects and the stress state in both components of the two-layer systems 
$\mathrm{Ni}_{1-x} \mathrm{~W}_{x} \mid \mathrm{TiN}$ provide an opportunity to solve the main task of this research i.e. to establish the nature and physical mechanisms of the processes of texture formation in the system $\mathrm{Ni}-9.5$ at. $\% \mathrm{~W} \mid \mathrm{TiN}$.

In the two-layer composition $\mathrm{Ni}-5$ at. $\% \mathrm{~W} \mid \mathrm{TiN}$, in which the material of substrate has rather high value of stacking fault energy and as a consequence possesses the developed cubic texture, the interaction with the coating leads to increase in the stress level in the metallic tape. While the macrostrains in the TiN subsystem are practically inexistent. As noted earlier [18], with increase in the TiN layer thickness, the texture tends to get a bit weaker.

By using substrate based on $\mathrm{Ni}-5$ at. $\%$ W alloy, apparently, one could create an "ideal" system, in which the optimal conditions for texture formation are realized according to the scheme $\{001\}_{\mathrm{Ni}}-5$ at. \% $w\left\|\{001\}_{\text {TiN }}\right\|\{001\}_{\text {YBCO-123 }}$. However, the current-carrying capacity of a given composition on alternating current should be markedly degraded due to the high level of ferromagnetic losses [37].

It is obvious that more promising system for electric charge transfer is the composition using, as a substrate, the tape based on the paramagnetic alloy $\mathrm{Ni}-9.5$ at. $\% \mathrm{~W}$.

In this paper it is established that the scenario of the onset and evolution of the stress state and the processes of texture formation in the two-layer composition $\mathrm{Ni}$ - 9.5 at. $\% \mathrm{~W} \mid \mathrm{TiN}$ is fundamentally different from the scenario of texture formation in the system $\mathrm{Ni}-5$ at. $\% \mathrm{~W} \mid \mathrm{TiN}$.

The main difference is as follows: in the TiN layer deposited onto substrate of $\mathrm{Ni}-$ 9.5 at. $\% \mathrm{~W}$, the compressive stresses occur (see Fig. 4c). This circumstance is a consequence of the process of redistribution of the stress state in the two-layer system $\mathrm{Ni}$ - 9.5 at. $\%$ W|TiN as a result of the mutual influence of the substrate and coating. As emerges from the above data (see Fig. 2), as a result of the interaction of the substrate and coating layers, rather strong cubic texture appears in the TiN buffer layer, the intensity of which is practically comparable to the intensity of the TiN texture in the system $\mathrm{Ni}-5$ at. $\% \mathrm{~W} \mid \mathrm{TiN}$. Moreover the cubic texture of the metallic layer of the system $\mathrm{Ni}-9.5$ at. $\% \mathrm{~W} \mid \mathrm{TiN}$ noticeably intensifies under the influence of the strong compressive stresses of TiN.

The obtained data indicate the possibility of realization of three-layer compositions with architecture of the following type
$\{001\}_{\mathrm{Ni}}-9.5$ at. \% w\| $\left\|\{001\}_{\mathrm{TiN}}\right\|\{001\}_{\text {YBCO-123 }}$, which has a great potential for creating the 2G HTS superconductors with the high current-carrying capacity.

\section{Conclusions}

The main results of the research on the problem of establishing the nature and mechanisms of the processes of texture formation in the system $\mathrm{Ni}_{1-x} \mathrm{~W}_{x} \mid \mathrm{TiN}$ by comparative study of two-layer compositions based on the ferromagnetic alloy $\mathrm{Ni}-5$ at. $\% \mathrm{~W}$ and the paramagnetic alloy $\mathrm{Ni}-$ 9.5 at. $\% \mathrm{~W}$ are as follows:

Conditions for obtaining the two-layer systems $\mathrm{Ni}-5$ at. $\% \mathrm{~W} \mid \mathrm{TiN}$ and $\mathrm{Ni}-$ 9.5 at. $\% \quad W \mid$ TiN are developed and optimized.

The algorithm for studying the interphase stresses in two-layer systems $\mathrm{Ni}_{1-}$ ${ }_{x} \mathrm{~W}_{x} \mid \mathrm{TiN}$, based on modernization of the known " $\sin ^{2} \psi$ " method with respect to twolayer systems is developed.

The nature of the processes of texture formation in the $\mathrm{Ni}_{1-x} \mathrm{~W}_{x} \mid \mathrm{TiN}$ systems is established. It is shown that the mechanisms and kinetics of the processes of formation of the cubic texture in both components of the thin-film system depend on the composition of the metallic component $\mathrm{Ni}_{1-x} \mathrm{~W}_{x}$ and the method of coating deposition.

It is established that the driving force of the processes of texture formation in both components of the two-layer system $\mathrm{Ni}-$ 9.5 at. $\% \mathrm{~W} / \mathrm{TiN}$ is redistribution of the level of the stress state on each side of the interface boundary.

The strategy of obtaining the textured substrates based on the paramagnetic alloy $\mathrm{Ni}-9.5$ at. $\% \mathrm{~W}$, providing the possibility of creating the efficient $2 \mathrm{G}$ HTS with the architecture of the following type $\mathrm{Ni}-$ $\mathrm{W}|\mathrm{TiN}| \mathrm{YBCO}-123$ is developed.

\section{References}

1. A.Goyal, D.P.Norton, J.D.Budai et al., Appl, Phys, Lett., 69, $1795 \quad$ (1996). DOI: 10.1063/1.117489.

2. B.Seeber, Power Applications of Superconductivity: Handbook of Applied Superconductivity. Bristol, UK: Inst. Physics (1998).

3. A.P.Malozemoff, Y.Yamada, Coated Conductor: Second Generation HTS Wire. In 100 Years of Superconductivity. ed. by H.Rogalla, P.Kes, New York:Taylor \& Francis (2011).

4. M.W.Rupich, X.Li, C.Thieme et al., Supercond, Sci.Technol., 23, 014015 (2010). DOI: 10.1088/0953-2048/23/1/014015. 
5. A.Vannozzi, A.Augieri, G.Celentano et al., $J$ Alloys Comp., 735, 454 (2018). DOI: 10.1016/j.jallcom.2017.11.149

6. U.Gaitzsch, J.Hanisch, R.Huhne et al., Supercond, Sci, Technol., 26, 085024 (2013). DOI:10.1088/0953-2048/26/8/085024.

7. U.Gaitzsch, J.Eickemeyer, Ch.Rodig, Scr, Mater., 62, 512 (2010). DOI: 10.1016/j.scriptamat.2009.12.030.

8. Yue Zhao, HongLi Suo, Min Liu et al., Acta Mater., 55, 2609 (2007) DOI:10.1016/j.actamat.2007.01.001.

9. R.Huhne, R.Gartner, S.Oswald et al., Physica $C, 471,966$ (2011).

DOI: $10.1016 /$ j.physc.2011.05.101.

10. R.Huhne, S.Fahler, B.Holzapfel, Appl, Phys, Lett., 85, 2744 (2004) DOI: 10.1063/1.1802385.

11. R.Huhne, K.Guth, M.Kidszun et al., J, Phys, D: Appl,Phys., 41, 245404 (2008). DOI: 10.1088/0022-3727/41/24/245404.

12. J.Eickenmeier, R.Huhne, A.Guth et al., $\mathrm{Su}$ percond, Sci, Technol., 23, 085012 (2010). DOI: $10.1088 / 0953-2048 / 23 / 8 / 085012$.

13. A.O.Ijodola, J.R.Thomson, A.Goyal et al., Physica C, 403, 163 (2004). DOI: 10.1016/j.physc.2003.12.003.

14. Y.A.Genenko, H.Rauh, P.Kruger, Appl,Phys, Lett., 98, 152303 (2011). DOI: 10.1063/1.3560461.

15. S.V.Subramanya, J.Eickemeyer, L.Schultz et al., Scripta Mater., 50, 953 (2004) DOI: 10.1016/j.scriptamat.2004.01.004.

16. F.A.Mohamed, T.G.Langdon, Mettalurgical Trans.A., 6, 927 (1975).

17. D.J.Siegel, Appl,Phys,Lett., 87, 121901 (2005). DOI: 10.1063/1.2051793.

18. V.A.Finkel, A.M.Bovda, S.A.Leonov et al., Functional Materials, 19, 109 (2012).

19. V.A.Finkel, V.V.Derevyanko, M.S.Sunhurov et al., Functional, Materials, 20, 103 (2013) DOI: $10.15407 / \mathrm{fm} 20.01 .103$.

20. M.S.Sungurov, V.V.Derevyanko, S.A.Leonov et al., Tech, Phys, Lett., 40, 797 (2014). DOI: 10.1134/S1063785014090314.

21. M.S.Sunhurov, S.A.Leonov, T.V.Sukhareva et al., Functional, Materials, 24, 063 (2017) DOI: $10.15407 / \mathrm{fm} 24.01 .063$.

22. V.V.Derevyanko, M.S.Sunhurov, T.V.Sukhareva et al., IEEE Explore: 2017 IEEE In- tern. Young Scient. Forum Appl. Phys. Engin. (YSF), Lviv, 167 (2017). DOI: 10.1109/YSF.2017.8126611.

23. M.S.Sunhurov, V.A.Finkel, JTP, 3, (2018). In press.

24. Y.Zhao, H.L.Suo, Y.Zhu et al., Supercond, Sci, Technol., 21, $075003 \quad$ (2008) DOI: 10.1088/0953-2048/21/7/075003.

25. V.A.Belous, V.V.Vasiliev, A.A.Luchaninov et al., J. Surf. Phys. Engin., 7, 216 (2009).

26. I.I.Aksenov, A.N.Belokhvostikov, V.G.Padalka et al., Plasma Phys, Control, Fusion., 28, 761 (1986).

27. I.I.Aksenov, A.A.Andreev, V.A.Belous, Vacuum Arc, Naukova Dumka, Kyiv (2012).

28. L.S.Palatnik, Proc. Kharkiv State Univ., 7, 245 (1950).

29. F.R.Aliaj, N.Syla, H.Oettel et al., Surf. Interface Anal., 49, 1135 (2017) DOI: 10.1002 /sia.6292.

30. Yu.I.Sirotin, M.P.Shoskolskaya, Basics of Crystallography, Nauka, Moscow (1979) [in Russian].

31. A.Sonin, Course of Macroscopic Crystallography, Fizmatlit, Moscow (2016) [in Russian].

32. M.M.Borodkina, E.N.Spector, X-ray Diffraction Analysis of the Texture in Metals and Alloys, Metallurgiya, Moscow (1981) [in Russian].

33. D.Hudson, Statistics for physicists, Mir, Moscow, p. 296 (1970).

34. L.I Gladkikh, S.V Malykhin, A.T.Pugachev, Diffraction Methods for Analysis of Internal Stresses (Theory and Experiment), NTU KPI, Kharkov (2006) [in Russian].

35. V.Hauk, Structural and Residual Stress Analysis by Non-destructive Methods, Evaluation, Application, Assessment, Elsevier (1997).

36. M.S.Sunhurov, T.V.Sukhareva, V.A.Finkel, IEEE Explore: 2016 II International Young Scientists Forum on Applied Physics and Engineering (YSF), Kharkiv (2016), p.96 DOI: 10.1109/YSF.2016.7753810.

37. Y.Mawatari et al., Supercond,Sci.Technol., 23, 025031 (2010). 